\title{
Early development of eye and retina in lanternfish larvae
}

\author{
A. BOZZANO, ${ }^{1}$ P.M. PANKHURST, ${ }^{2}$ AND A. SABATÉS ${ }^{1}$ \\ ${ }^{1}$ Institut de Ciències del Mar (CSIC), Barcelona, Spain \\ ${ }^{2}$ School of Marine Biology and Aquaculture, James Cook University, Townsville, Queensland, Australia
}

(Received December 5, 2006; AcCePted April 30, 2007)

\begin{abstract}
The morphological characteristics of the eyes and the retinae of lanternfish larvae of Lampanyctus crocodilus, Benthosema glaciale, and Myctophum punctatum were analyzed in pre-flexion, flexion, and post-flexion stages. Pre-flexion larvae of $L$. crocodilus, the species with the shallowest depth distribution, had spherical eyes located antero-laterally on a strongly laterally-compressed head, suggesting a forward binocular visual field. B. glaciale and $M$. punctatum larvae live deeper in the water column and had eyes elongated in the dorsal-ventral plane. The eyes of B. glaciale were prominent, projecting slightly outward from a laterally-compressed head, suggesting a strongly laterally-directed visual field. $M$. punctaum had stalked elongated eyes projecting from a dorso-ventrally flattened head. The eyes can be freely rotated allowing lateral, anterior and dorsally-directed vision. A prominent choroidal gland was situated beneath the ventral portion of the eye in M. punctatum and B. glaciale, while a smaller gland was present in the dorsal and ventral portions of the eye of L. crocodilus. In pre-flexion stage larvae, the retina of all three species was differentiated with numerous rod photoreceptors in the peripheral retinal areas and fewer cone photoreceptors mainly distributed in the central retina. This distribution suggests concomitant enhancement of scotopic sensitivity in the vertical visual plane and improved photopic acuity in the lateral and forward visual directions. The concurrent development of cones and rods, as observed in the pre-flexion stage of myctophid larvae, is consistent with meeting the special demands of visual planktivory in sub-surface waters. During larval development a gradual increase of ROS length was also accompanied by a progressive loss of cones that were almost totally absent in post-flexion larvae. This can be interpreted as an adaptive response to an impending deep mesopelagic adult life.
\end{abstract}

Keywords: Larvae, Myctophidae, Eye shape, Retina, Development

\section{Introduction}

Most marine fish larvae hatched from small pelagic eggs are strongly visual predators at feeding onset (Blaxter, 1986; Pankhurst \& Hilder, 1998; Rodríguez \& Gisbert, 2002). Initially, the retinae of these larvae are characterized by the exclusive presence of cone photoreceptors, limiting visual function to photopic conditions in near-surface waters, in which light intensities are relatively high (Blaxter, 1986; Powers \& Raymond, 1990). It has been suggested that the small eye size of fish larvae constrains concurrent development of rod and cone photoreceptors, and that the ecological demands for visual planktivory results in optimization of acute visual resolution, a cone function, at the expense of sensitivity (Kotrschal et al., 1990). In these larvae, capacity for vision under scotopic conditions, or with increasing depth, develops with the subsequent development of rod photoreceptors (scotopic sensitivity) and with cone enlargement (photopic sensitivity). Increasing visual sensitivity during development of shallow water larvae frequently coincides with increasing depth distribution and change

Address correspondence and reprint requests to: Anna Bozzano, Institut de Ciències del Mar (CSIC), Passeig Marítim de la Barceloneta 37-49, E-08003 Barcelona, Spain. E-mail: bozz@icm.csic.es in feeding ecology (Kawamura et al., 1984; Shand, 1997). In contrast to shallow water larvae, little is known of the visual ontogeny and ecology of deep-dwelling larvae.

In this respect, mesopelagic fish larvae belonging to the family Myctophidae (lanternfish) represent an extremely interesting example. Feeding ecology of most adult lanternfish involves daily vertical migrations, fish moving between 350 and $450 \mathrm{~m}$ in depth in order to feed in the sub surface-water layer (upper $100 \mathrm{~m}$ ) at night (Sameoto, 1988; Hopkins \& Gartner, 1992). In contrast, lanternfish larvae are presumed to be visual predators, feeding during the daytime (Sabatés et al., 2003), suggesting a marked ontogenetic shift in their feeding ecology and behavior.

Lanternfish larvae exhibit a high diversity of morphological traits (Moser, 1981), among which eye shape is one of the most important. Larvae fall into two groups on the basis of eye shape: those with narrow elliptical eyes (in some genera they are borne on stalks) and those with round or nearly round eyes (Moser \& Ahlstrom, 1970, 1974). The species composition of these two groups of lanternfish agrees closely with that of the two subfamilies, Myctophinae and Lampanyctinae, established by Paxton (1972) on the basis of osteological and photophore characters of adults. It has been suggested that these differences in morphological (and likely physiological) characteristics of the eyes of 
lanternfish larvae might result in different feeding strategies (Sabatés \& Saiz, 2000, Sassa \& Kawaguchi, 2005).

In this study, larvae of two Myctophinae (Myctophum punctatum and Benthosema glaciale) and one Lampanyctinae (Lampanyctus crocodilus) species at the pre-flexion, flexion and postflexion stages were investigated. The larvae of $L$. crocodilus, a species with round eyes, show a relatively shallow depth distribution, preferentially in the upper $30 \mathrm{~m}$ of the water column (Olivar \& Sabatés, 1997). At these depths light intensity in the Mediterranean Sea at the end of summer can vary between 600 and $200 \mu \mathrm{mol} \mathrm{s}{ }^{-1} \mathrm{~m}^{2}$ (Sabatés et al., 2003) at midday. The larvae of B. glaciale show an intermediate distribution between 20 and $100 \mathrm{~m}$ where maximum light intensity ranges between 200 and $1.3 \mu \mathrm{mol} \mathrm{s}{ }^{-1} \mathrm{~m}^{2}$ while larvae of $M$. punctatum have a deep distribution in the water column between 50 and $150 \mathrm{~m}$ (Olivar et al., 1998; Sabatés, 2004), and a maximum available light between 22 and $0.1 \mu \mathrm{mol} \mathrm{s}{ }^{-1} \mathrm{~m}^{2}$. The larvae of the two latter species have elliptical eyes, and in the case of M. punctatum, they are also borne on stalks. All three species are known to be visual predators as they feed during daylight hours and in addition to this, foraging strategies are reported to vary in relation to ambient light intensity (Sabatés et al., 2003).

Taking into account that the early ontogeny of fish larvae can be regarded as a trade-off between environmental abiotic factors (for example, light intensity and photoperiod), functional demands (feeding strategies and depth distribution) and developmental stages, in this study, it is hypothesized that such a relation between ecological needs and structural differentiations may exist in the eye of the lanternfish larvae.

\section{Materials and methods}

\section{Field sampling and histological analysis}

Lanternfish larvae were collected in the Western Alboran Sea (Western Mediterranean) during a research cruise conducted from May 2 to 16, 1998. The sampling was performed at three stations located in a transect perpendicular to the coast $\left(36^{\circ} 00^{\prime} \mathrm{N}-36^{\circ} 23^{\prime}\right.$ $\left.\mathrm{N}, 4^{\circ} 14^{\prime} \mathrm{W}-4^{\circ} 16^{\prime} \mathrm{W}\right)$. A different station was sampled each day, both during day and night. Fish larvae were collected with Bongotype plankton net with a mouth opening $60 \mathrm{~cm}$ in diameter and a mesh size of $333 \mu \mathrm{m}$. The tows were carried out from a maximum depth of $200 \mathrm{~m}$, at a ship speed of $3.7 \mathrm{~km} \mathrm{~h}^{-1}$ ( 2 knots).

Upon capture, a total of 54 individuals of lanternfish larvae of L. crocodilus $(n=16)$, B. glaciale $(n=19)$, and M. punctatum $(n=17)$ were separated on board and fixed overnight in a solution of $2.5 \%$ glutaraldehyde, $1 \%$ paraformaldehyde in $0.1 \mathrm{M}$ phosphate buffer $\mathrm{pH} 7.4$ to which $3 \%$ sucrose was added in order to provide a fixative that was near-isotonic with seawater fish tissue and therefore reduced tissue shrinkage. In myctophid fish larvae shrinkage has been reported to be ca. 3-7\% (Moku et al., 2001, 2004) with formalin seawater and ethyl alcohol freshwater fixatives. The use of sucrose in the fixative we employed, we assume to have reduced this value. Therefore, no correction was applied to larval fish measurements. After fixation, the samples were transferred to $0.1 \mathrm{M}$ phosphate buffer and maintained at $4^{\circ} \mathrm{C}$ until reaching the laboratory. Larvae were classified into pre-flexion, flexion and post-flexion stages. Standard length (SL) was measured, using light microscopy (to the nearest $0.1 \mathrm{~mm}$ ), from the tip of the snout to the end of the notochord in pre-flexion and flexion larvae, and from the tip of the snout to the posterior margin of the hypural plate in post-flexion larvae.
Dorso-ventral (DV) and rostro-temporal (RT) eye diameters were measured prior to embedding and the relative eye size (DV/SL and RT/SL) was calculated. In each developmental stage, the relationship DV/RT was used to calculate the elliptical index, (elliptical index of a spherical eye $=1$ ).

Twelve individuals of each species were subsequently dehydrated in a graded ascending series of ethanol-water mixtures and infiltrated in plastic resin (Historesin-Leica) overnight. A total of four (five for pre-flexion stage) individuals from each development stage were oriented and embedded for transverse or horizontal sectioning. Serial sections $(2-3 \mu \mathrm{m})$ were cut and stained with methylene blue and basic fucsin (Lee's staining procedure, www. ebsciences.com). Cell morphometrics and measurements of the lens dimensions were taken in the central retina in sections with the largest lens diameter. Photoreceptor outer segment length and linear densities of photoreceptors and putative ganglion cell nuclei were measured along a $100 \mu \mathrm{m}$ linear transect in the dorsal, central and ventral regions of the retina, away from the optic nerve and falciform process, using a light microscope and the Optimas 6.0 image analyzer. For the calculation of putative ganglion cell density, a prior cell somata analysis of the cells in the ganglion cell layer (GCL) was done. The cell soma areas were measured using the Optimas 6.0 image analyzer and the putative displaced amacrine cells (DACs), which do not contribute to visual acuity and that are known to be located within the GCL (Collin, 1988; Collin \& Pettigrew, 1988; Wagner et al., 1998; Mack et al., 2004), were differentiated on morphological grounds according to criteria identified by Collin (1988). Small, circular, deep-stained somas were putatively associated with the DACs, while the large, granular, and irregularly shaped profiles were attributed to putative ganglion cells (GCs). Angular cell density was calculated for rods, cones and putative GCs, according to Poling and Fuiman (1998), including an adjustment for a potential error in linear ganglion cell densities associated with the angular curvature of small eyes. Visual acuity intended as minimum separable angle (MSA) was calculated using a modification of the equation given by Neave (1984) as proposed by Poling and Fuiman (1998). It is worth noting that there is a considerable morphological and functional diversity among GCs. Hirt and Wagner (2005) identified up to 10 different types of GCs in a deep sea fish and not all of them contributed to visual acuity. Thus, in the present study, ideally we should have at least distinguished between $\mathrm{ON}$ and OFF centre ganglion cells, but the ship-board sampling precluded this physiological approach. Therefore, the ganglion cell density we calculated contributing to the optic tectum input for acute visual resolution could be overestimated by $50 \%$.

One individual of each development stage was used to examine retinal ultrastructure. After primary fixation onboard ship, the larvae were post-fixed in $1 \%$ osmium tetroxide and embedded in Spurr resin. Ultrathin sections $(0.5-0.6 \mu \mathrm{m})$ in the transverse plane were stained with lead citrate and uranyl acetate and examined using a Hitachi 600AB transmission electron microscope TEM.

A Student's $t$-test was used to compare the effect of retinal region and larval growth on the rod-like photoreceptor length and density, as well as on the putative ganglion cells. The effect of retinal region on the cone-like photoreceptors was tested only in pre-flexion stage larvae, while no test was performed in flexion and post-flexion stages due to the non-uniform distribution of the cones. For each retinal region, interspecific changes in the rod-like photoreceptor length and density, as well as in putative ganglion cell density were also tested. 


\section{Results}

\section{Shape and position of the eye}

At the pre-flexion stages, the eyecup of all three species appeared dark due to the retinal pigment epithelium (RPE) situated adjacent to the sclera. The lens and the cornea of all larvae bulged out of the eyecup. The position and orientation of the eyes in the head of each species are shown in Fig. 1.

In L. crocodilus larvae, the species with the shallowest depth distribution, the eyes were positioned on a strongly laterally compressed head and angled obliquely inward toward the snout (Fig. 1,
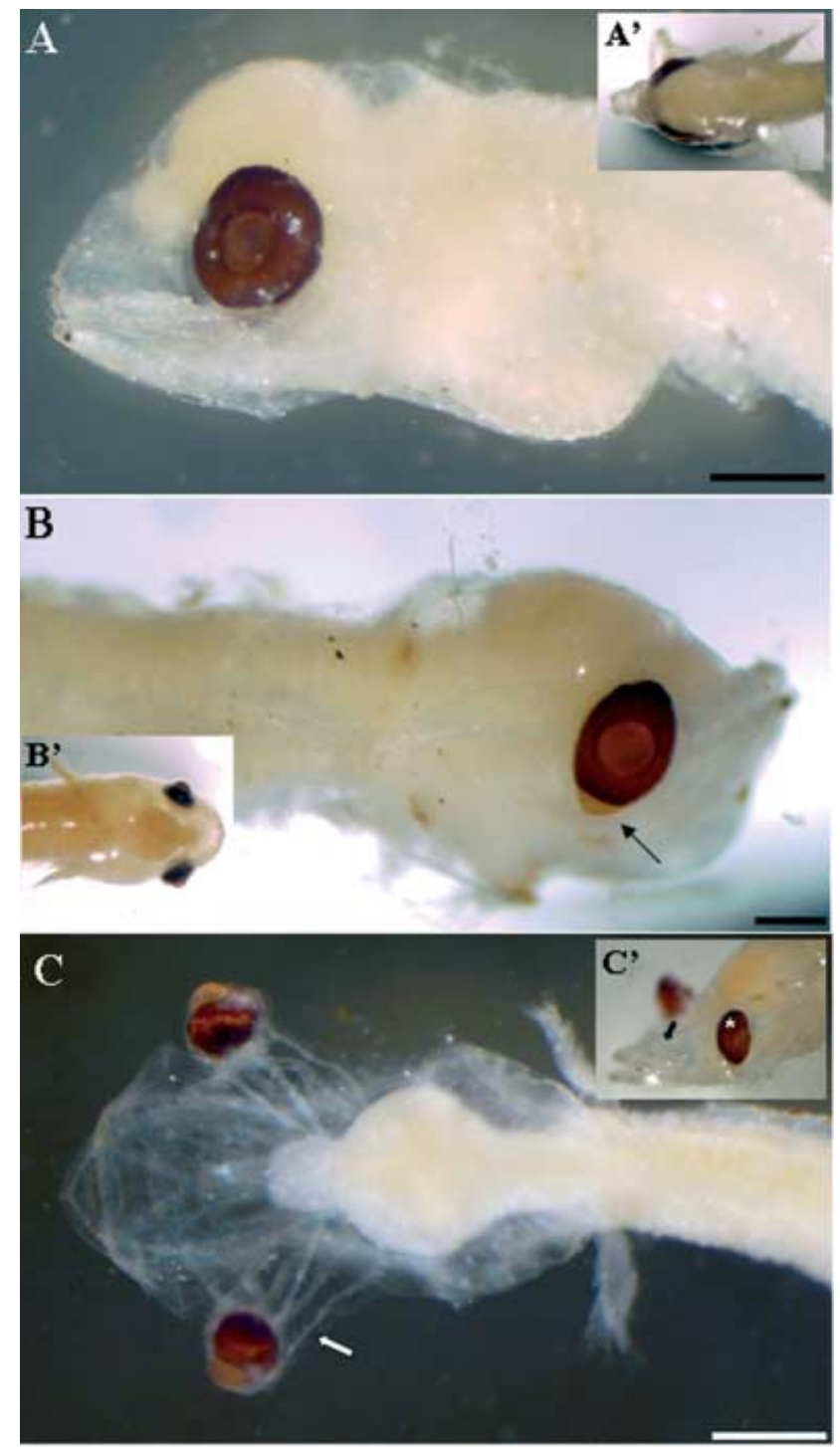

Fig. 1. Photographs of lanternfish larvae prior to flexion. (A) Lampanyctus crocodilus larva $(5.04 \mathrm{~mm} \mathrm{SL})$ in lateral view showing a near-spherical eye. Inset: L. crocodilus $(4.76 \mathrm{~mm} \mathrm{SL})$ viewed from above showing the lateral orientation of the eyes in the head. (B) Benthosema glaciale larva $(5.2 \mathrm{~mm} \mathrm{SL})$ in lateral view showing an elliptical eye. The arrow indicates the choroidal gland. Inset: B. glaciale larva $(7.04 \mathrm{~mm} \mathrm{SL})$ in dorsal view. (C) Myctophum punctatum larva $(5.6 \mathrm{~mm} \mathrm{SL})$ in dorsal view showing the stalked (white arrow) eyes. Inset: $M$. punctatum larva $(7.64 \mathrm{~mm} \mathrm{SL})$ in lateral view showing the elliptical eyes (asterisk), reduction of eyestalks and the dorso-ventrally flattened head (black arrow). Scale bar: $0.5 \mathrm{~mm}$. inset). They were proportionally larger than the eyes of the other two species and almost spherical (Fig. 1A, Table 1), with mean elliptical indices of $0.99 \pm 0.1$ and $0.87 \pm 0.06$ in pre-flexion and post-flexion larvae, respectively (Fig. 2). After the examination of all the serial sections of the entire eye, a small choroidal gland was observed in the dorsal and ventral portions of the eye (Fig. 3A). The eyes of $B$. glaciale larvae were more prominent than those of $L$. crocodilus, projecting further outward from the head and were less obliquely angled toward the snout (Fig 1, inset). The eyes of this species were elongate in the dorso-ventral plane (Fig. 1B, Table 1) with a mean elliptical index of $0.69 \pm 0.05$ that remained fairly constant during larval development (Fig. 2). In addition, the eye had a pronounced ventral choroidal gland, especially noticeable in the pre-flexion stage (Figs. 1B, 3B). It appeared as a conical mass of highly vascularised conjunctive tissue. In $M$. punctatum larvae, the species with the deepest distribution, eyes were extended on stalks arising from the anterior region of the forebrain (Fig. 1C). They showed the smallest relative size especially in the rostro-temporal plane and were elongated in the dorso-ventral plane (Fig. 1, inset, Table 1) with a mean elliptical index of $0.53 \pm 0.1$ at the pre-flexion stage. Attenuation of the optic stalk occurred in the post-flexion stage coincident with a progressive rounding of the eye (elliptical index of $0.61 \pm 0.06$ ) (Fig. 2). A prominent choroidal gland located beneath the ventral portion of the eye (Fig. 3C) was also observed in this species.

\section{Retinal morphometry}

\section{Pre-flexion larvae}

At this stage, the retina was well developed in all three species of lanternfish and the eyes were presumed to be fully functional, as evident by differentiation of all retinal cell layers (Fig. 4), pigmentation of the RPE, crystallization of the lens (a result of water extrusion from cells and concentration of crystalline and protein fractions responsible for lens transparency and high refractive index; Nicol (1989) and the optic nerve contacting the optic tectum.

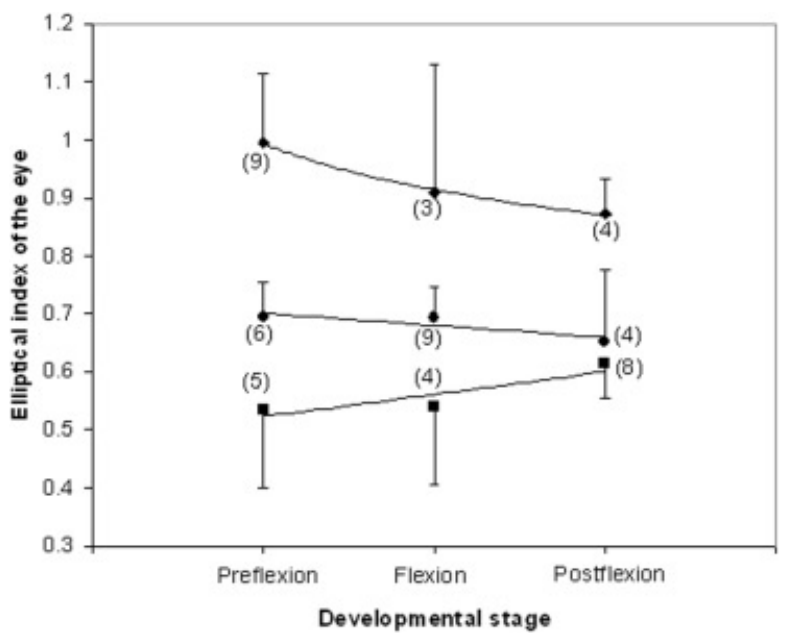

Fig. 2. Changes in the elliptical index of the eye during growth in Lampanyctus crocodilus (rhombus, $y=0,99 \mathrm{x}^{-0,12}, r^{2}=0,99$ ), Benthosema glaciale (circles, $y=0,72 \mathrm{e}^{-0,03 \mathrm{x}}, r^{2}=0,76$ ) and Myctophum punctatum (squares, $y=0,49 \mathrm{e}^{0,07 \mathrm{x}}, r^{2}=0,80$ ). Values are means $\pm \mathrm{SD} ; n$ values are provided in brackets beside mean values. 
Table 1. Measurements of the eye and lens diameters in the three lanternfish larvae examined during each development stage. The relative eye size is expressed as the relation between the standard length (SL) and the DV (dorso-ventral) and RT (rostro-temporal) eye diameters. Lens diameter is expressed as mean \pm standard deviation. Depth range, standard length (SL) and number of examined individuals are also indicated

\begin{tabular}{|c|c|c|c|c|c|c|c|}
\hline Species & $\begin{array}{l}\text { Depth } \\
\text { range* } \\
(\mathrm{m})\end{array}$ & $\begin{array}{l}\text { Developing } \\
\text { stage }\end{array}$ & $\mathrm{n}$ & $\begin{array}{c}\text { SL } \\
(\mathrm{mm})\end{array}$ & $\begin{array}{c}\text { DV/SL } \\
(\%)\end{array}$ & $\begin{array}{c}\mathrm{RT} / \mathrm{SL} \\
(\%)\end{array}$ & $\begin{array}{l}\text { Lens } \\
\text { diameter } \\
(\mu \mathrm{m})\end{array}$ \\
\hline \multirow[t]{3}{*}{ L. crocodilus } & \multirow[t]{3}{*}{$<30 \mathrm{~m}$} & Pre-flexion & 5 & $4.35-5.04$ & 9.1 & 9.0 & $153.0 \pm 18.3$ \\
\hline & & Flexion & 3 & $6.3-6.85$ & 11.4 & 9.9 & $260.7 \pm 10.2$ \\
\hline & & Post-flexion & 3 & $8.88-9.76$ & 9.2 & 8.0 & $308.2 \pm 7.2$ \\
\hline \multirow[t]{3}{*}{ B. glaciale } & \multirow[t]{3}{*}{$20-100$} & Pre-flexion & 5 & $4.2-5.48$ & 8.8 & 6.7 & $169.4 \pm 22.6$ \\
\hline & & Flexion & 2 & $7.2-7.6$ & 7.7 & 6.2 & $229,1 \pm 17.3$ \\
\hline & & Post-flexion & 2 & $8.44-8.88$ & 7.9 & 5.7 & $242,6 \pm 5,0$ \\
\hline \multirow[t]{3}{*}{ M. punctatum } & \multirow[t]{3}{*}{$50-150$} & Pref-lexion & 4 & $5.15-6.08$ & 7.4 & 4.4 & $132.0 \pm 35.4$ \\
\hline & & Flexion & 2 & $8-8.16$ & 7.9 & 5.2 & $231.0 \pm 11.9$ \\
\hline & & Postf-lexion & 3 & $9.7-13.7$ & 6.8 & 4.8 & $277.4 \pm 30.6$ \\
\hline
\end{tabular}

*According to Olivar et al. (1998), Sabatés et al. (2003), and Sabatés (2004).

There were two types of photoreceptors evident in larvae of all species of lanternfish investigated: rod-like (presumptive rod) and cone-like (presumptive cone) photoreceptors (Fig. 5A). Presence of two morphologically distinct types of nuclei in a single-layered outer nuclear layer (ONL) supported this hypothesis. Identification of rod and cone photoreceptors was made in accordance with the morphological characteristics ascribed to each photoreceptor type (Ali \& Klyne, 1985). The nuclei of presumptive cones were sparsely distributed, round, light-stained with spread chromatin, whereas those of presumptive rods were more prevalent and dark-stained with concentrated chromatin (Figs. 5C-5E). A single pedicle-type synaptic process was observed in the outer plexiform layer (OPL) of the retina of all lanternfish larvae (Fig. 5B). Identification of a single synapse type may be a limitation associated with synapse differentiation at this developmental stage, and does not necessarily mean that only one type of synaptic process was present. In fact, it is possible that the classical morphological diagnostic characteristics of pedicles versus spherules are less

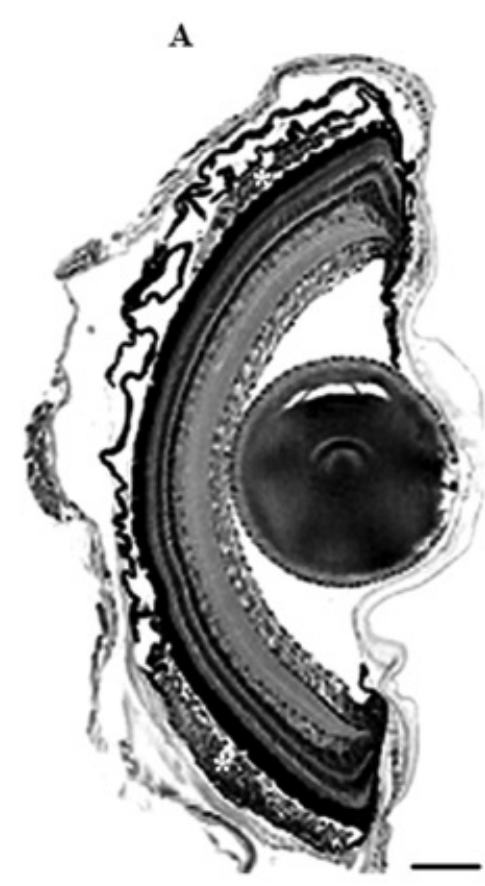

B

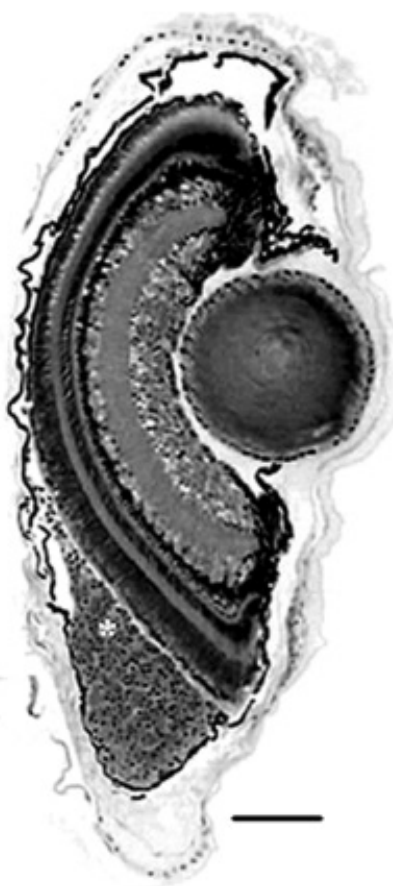

C

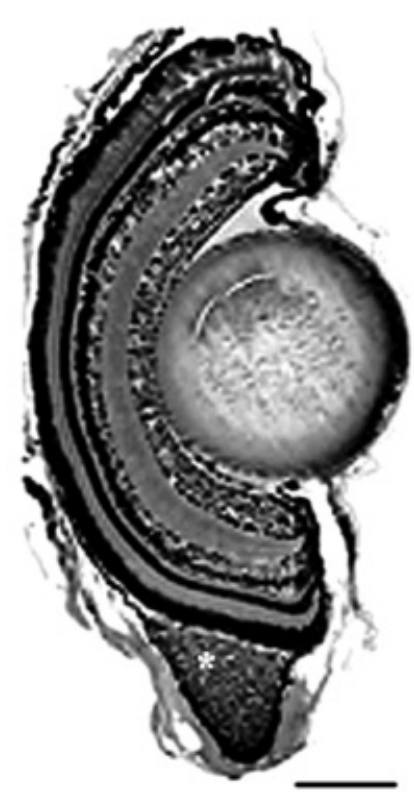

Dorsal

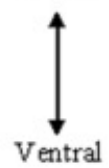

Fig. 3. Transverse sections of the eyes of lanternfish larvae in postflexion stages. (A) Lampanyctus crocodilus (9.5 mm SL), (B) Benthosema glaciale $(7.6 \mathrm{~mm} \mathrm{SL})$, and (C) Myctophum punctatum $(8 \mathrm{~mm} \mathrm{SL})$. Note the differences in the degree of development of the choroidal glands (asterisks). Scale bar: $100 \mu \mathrm{m}$. 


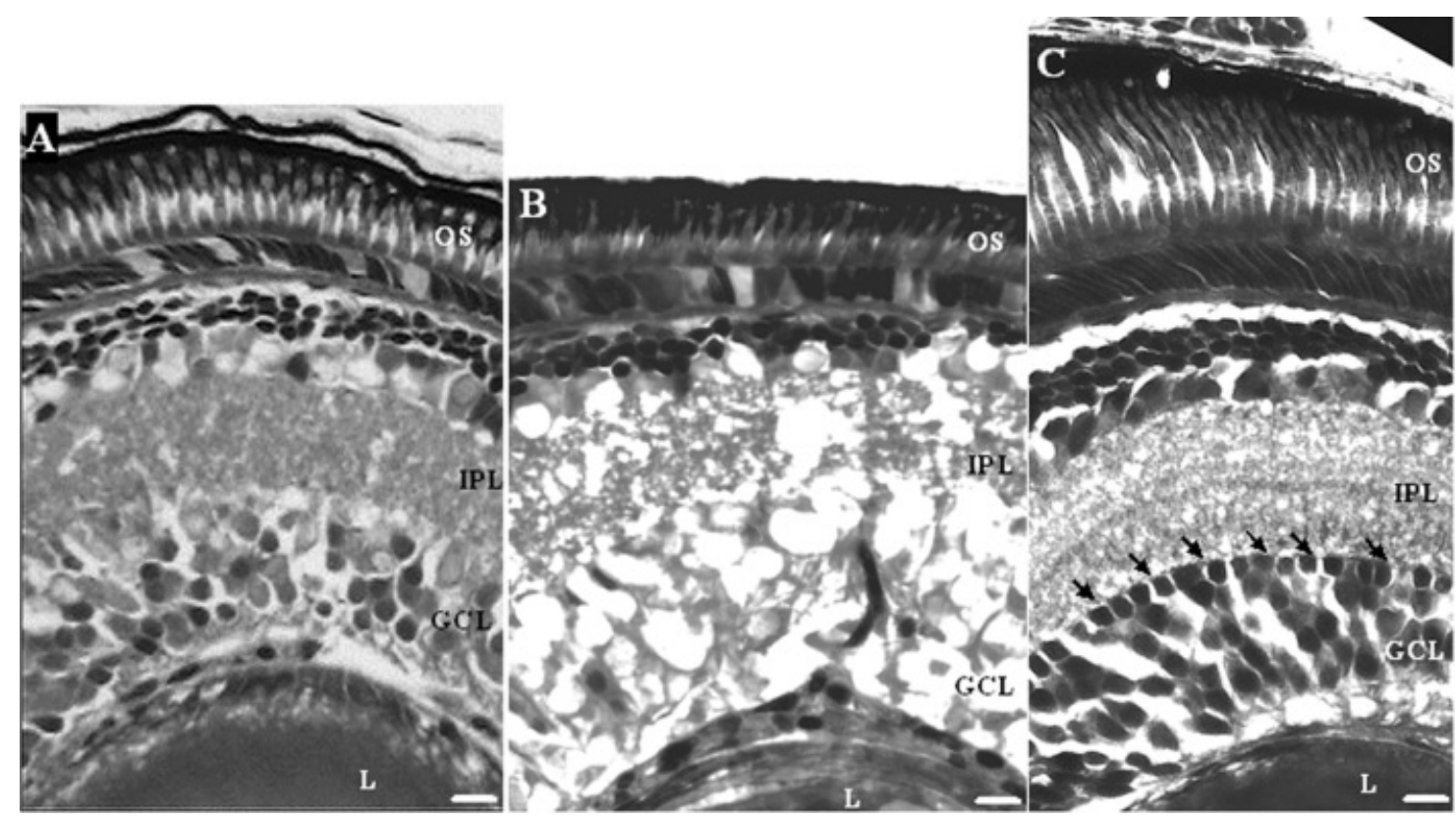

Fig. 4. Transverse sections of the retina of lanternfish larvae prior to flexion. (A) Lampanyctus crocodilus (4.4 mm SL), (B) Benthosema glaciale (4.3 mm SL), and (C) Myctophum punctatum (5.2 $\mathrm{mm} \mathrm{SL}$ ). L, lens; OS, photoreceptor outer segment; IPL, inner plexiform layer; GCL, ganglion cell layer. The black arrows indicate a row of putative displaced amacrine cells. Scale bar: $5 \mu \mathrm{m}$.

obvious at this stage. Rods had long slender outer segments (OSs) and TEM observations confirmed that the lamella discs within the OSs were discontinuous with the plasma membrane.

In the retina of $L$. crocodilus larvae, cones were observed mostly in the central retina (Table 2). The OSs was conical and the lamella discs appeared to be continuous with the plasma membrane. A cone accessory OS or "lateral sac," was sometimes observed running parallel with the cone outer segment, and numerous calycal processes were visible in tangential sections around the cone OS circumference (Fig. 5A). The inner segment of the rods of all three species contained mitochondria of uniform dimensions. The lighter staining ellipsoid of the cone photoreceptors was filled with wider aggregations of mitochondria full of vacuoles (Fig. 6).

In pre-flexion larvae of the lanternfish species examined, there were significant differences in rod OS length $(p<0.05)$ in relation to retinal region, with rod OS length longer in the dorsal and ventral regions compared to the central retina (Table 2). There were no significant differences among species $(p>0.05)$. Angular densities of rods were uniformly higher than that of cones in all retinal regions examined (Table 2 ) and did not vary throughout the retinal areas in any species, with the exception of $M$. punctatum, in which it was significantly higher in the central retina $(0.16 \pm 0.01$ cells 10 min $\left.\operatorname{arc}^{-1}\right)$. Angular densities of cones were highest in the central retina in $L$. crocodilus $\left(0.012 \pm 0.01\right.$ cells $\left.10 \mathrm{~min} \mathrm{arc}^{-1}\right)$, more evenly distributed throughout dorsal, ventral, and central regions of the ONL in B. glaciale $\left(0.02 \pm 0.01\right.$ cells $\left.10 \mathrm{~min} \operatorname{arc}^{-1}\right)$, whereas they had a patchy distribution in the ONL of $M$. punctatum, with highest densities in the dorsal retina $(0.013 \pm 0.01$ cells $10 \mathrm{~min} \mathrm{arc}^{-1}$ ) (Table 2). In all species, the putative displaced amacrine cells (DACs) constituted between 40 and $60 \%$ of the entire population of cells in the GCL and their soma was smaller than the putative ganglion cell soma (Figs. 4C, 7, Table 3). The summation ratio of rods: putative ganglion cells (GCs) was close to 2 in L. crocodilus, $2.5-4$ in B. glaciale and ca. 1.5 in $M$. punctatum. The summation ratio of cones: putative GC varied between $1.2-0.7$ in B. glaciale, $0.1-0.03$ in $M$. punctatum and $0.2-0.07$ in L. crocodilus (Table 2).

\section{Flexion larvae}

The outer retina showed evidence of cellular reorganization, as evident by the highly irregular arrangement of photoreceptor nuclei in the ONL, that appeared to be related to the loss of cone photoreceptors, particularly in the dorsal and central areas of the retina in L. crocodilus (Fig. 8A) and in the ventral and dorsal regions in the retina of $M$. punctatum (Figs. $8 \mathrm{~B}, 8 \mathrm{E}$ ) and $B$. glaciale (Fig. 8C). At the ultrastructure level, while the plasma membrane of cones appeared to remain intact, cone OS lost their regular compact lamella structure, developing large inter-membrane spaces and separation of lamella discs (Figs. 8D, 8E). At the same time, mitochondria within the cone ellipsoids appeared to be degenerating, showing ultrastructural vacuolization (Figs. 8D, 8E).

Flexion larvae showed no increase in either outer segment length or angular density of rods; however, a decrease in the angular density of putative GCs was observed in L. crocodilus and M. punctatum. Displaced amacrine cells constituted ca. $40 \%$ of the cells population in the GCL in B. glaciale and M. punctatum, while they reached $68 \%$ in $L$. crocodilus.

\section{Post-flexion larvae}

Long rod photoreceptor (OSs) were still observed in the dorsal and ventral retina of $M$. punctatum and B. glaciale, while a more homogeneous OS length distribution was observed in the retina of L. crocodilus (Table 2 ). The areas of cellular reorganization attributed to cone loss were still present in the dorsal ONL of $L$. crocodilus and $M$. punctatum and in the central region of the ONL in B. glaciale; however these areas were much reduced compared to earlier developmental stages. In all the retinal regions, the ONL was characterized only by rods (Fig. 9). The angular density of the putative GCs decreased further in L. crocodilus and M. punctatum, 

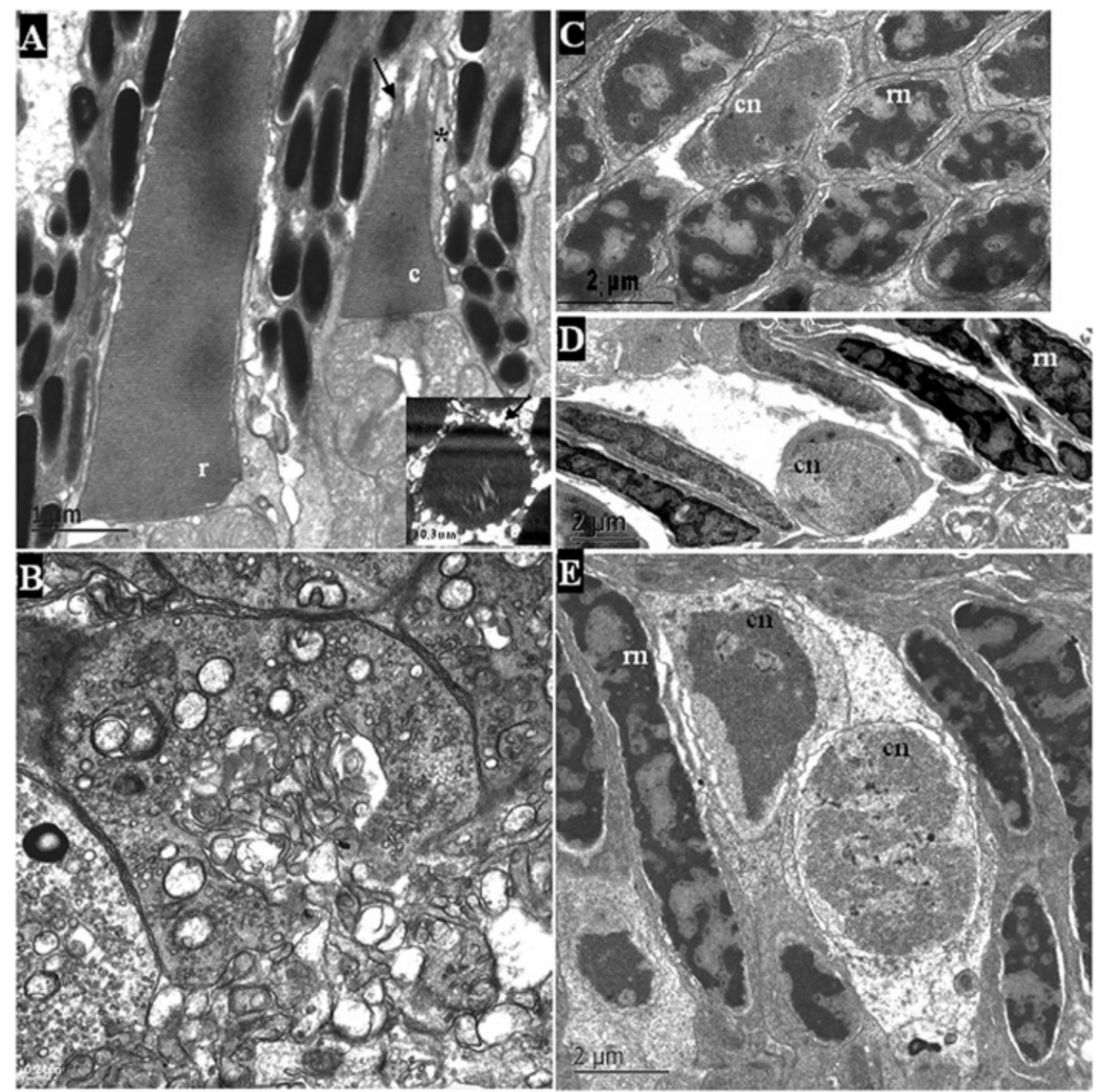

Fig. 5. Transmission electron micrographs of the retina of lanternfish larvae prior to flexion. (A) Outer segments of rod- (r) and single cone-like (c) photoreceptors in a Lampanyctus crocodilus larva (4.24 $\mathrm{mm} \mathrm{SL}$ ). Note the calycal processes (arrow) and the lateral sac (asterisk) of the presumptive cone outer segment. Inset: Tangential section of the outer segment of a putative cone showing numerous calycal processes (arrow). (B) Presumptive cone synaptic terminal in a Myctophum punctatum larva (6.12 mm SL). (C, D, and $\mathbf{E}$ ) presumptive rod ( $\mathrm{rn}$ ) and cone (cn) nuclei in retinae of L. crocodilus, B. glaciale and M. punctatum larvae, respectively.

while it maintained fairly constant in B. glaciale. Analysis of the summation ratio of rods: putative ganglion cells revealed that in $B$. glaciale and $M$. punctatum this relationship remained fairly constant, while in $L$. crocodilus it increased in all the retinal regions. The number of DACs increased only in L. crocodilus reaching $78 \%$ of the total cell population in the GCL, while in the other two species at this stage this value maintained practically constant (Table 3).

\section{Discussion}

\section{Preflexion stage}

Ontogeny of the larval eye for all three lanternfish species investigated involved changes in morphology of the retina and eye shape. Pre-flexion larvae had duplex retinae dominated by rod-like photoreceptors. The rod-like and cone-like photoreceptors found in the retinae of these species showed a number of ultrastructural features which they share with photoreceptors of other teleost larvae (Ali \& Klyne, 1985) and therefore they will be referred to as rods and cones. The presence of rods at this early stage of larval development is contrary to that reported for larvae of most shallow water marine fish, in which the retina is initially characterized by the exclusive presence of cones, rods only appearing later, close to, or at metamorphosis (Sandy \& Blaxter, 1980; Kawamura et al., 1984; Powers \& Raymond, 1990; Pankhurst \& Eagar, 1996; Shand 1997; Matsuoka, 1999; Shand et al., 1999a; Lara, 2001). In contrast, larvae of the Japanese eel, Anguilla japonica (7 days old reared larvae and $11.0 \mathrm{~mm}$ wild caught leptocephalus, ca. 2 weeks post-hatching) and of the deep sea sawtail fish Idiacanthus fasci- 
Table 2. Summary of the measurements of rod outer segment (ROS) length, and rod, cone and putative ganglion cells (GC) angular densities in different retinal regions during the lanternfish larvae development. Visual acuity (MSA) and summation ratios are also shown

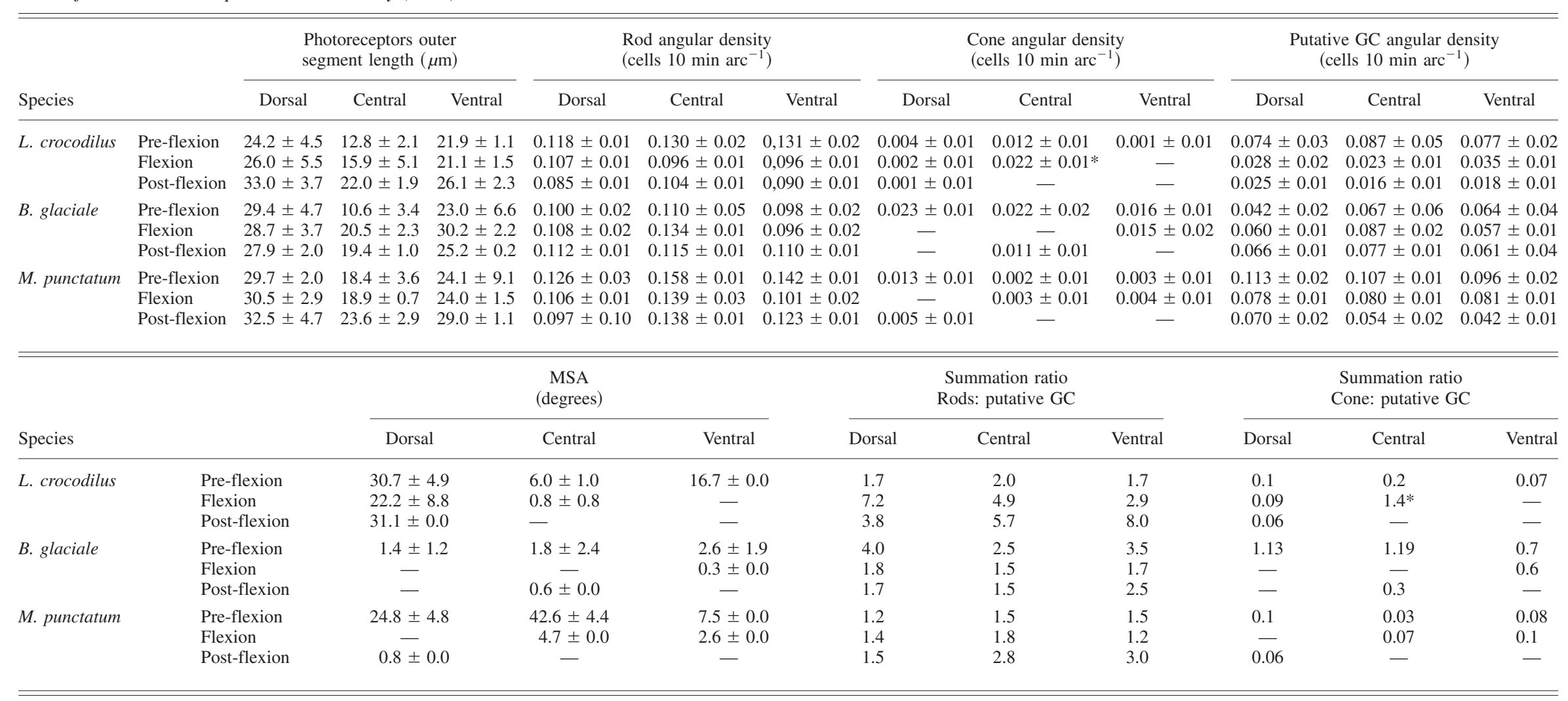

*These values are due to a large confused area found in one individual where cone nuclei were still present but the OS were degenerating. 


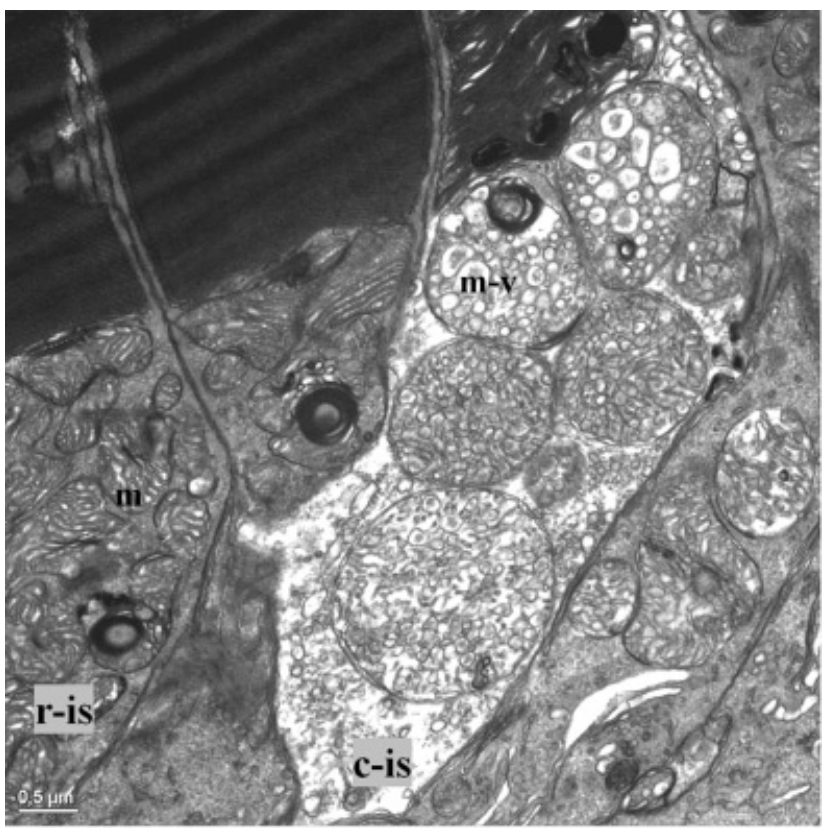

Fig. 6. Transmission electron micrographs of the rod-like (r-is) and conelike (c-is) photoreceptors inner segments of Myctophum punctatum. Rod ellipsoids are filled with mitochondria while cone ellipsoid is characterized by the presence of both mitochondria full of vacuoles $(\mathrm{m}-\mathrm{v})$. olatus were reported to have short cone-like photoreceptors in the centre of an otherwise rod-dominant retina (Omura et al., 1997; Wagner et al., 1998). In the present study, similar retinal morphology was observed in the pre-flexion lanternfish larvae investigated. On the other hand, the present study appears to be at odds with an early study by Pankhurst (1987) in which a pure rod retina was reported in a single larval specimen $(5 \mathrm{~mm} \mathrm{TL})$ of the myctophid Lampanyctodes hectoris, which mainly dwell in the upper levels of the water column (0-20m depth) (Olivar et al., 1992). However, the author acknowledged that in the absence of ultrastructural confirmation of photoreceptor type, identification of the photoreceptors as rods was open to question.

Early development of a rod-dominated retina is consistent with visual function under scotopic (dim light) conditions. While depth distribution of larvae of the three species of myctophids examined ranges from near-surface waters in L. crocodilus $(<30 \mathrm{~m})$, to $150 \mathrm{~m}$ in M. punctatum, scotopic sensitivity of pre-flexion larvae, as evident by the retinal morphological measurements of light path-length for photochemical stimulation (ROS lengths), angular densities of rods and summation ratios (rods: putative GCs), did not differ much between species, with the exceptions of $M$. punctatum with significantly higher angular density of rods in the central retina and $B$. glaciale with higher summation ratios in the dorsal and ventral retina. This certain overlap in their visual ecology is further supported by the consistent pattern in preflexion larvae of all three myctophid species of significant differ-

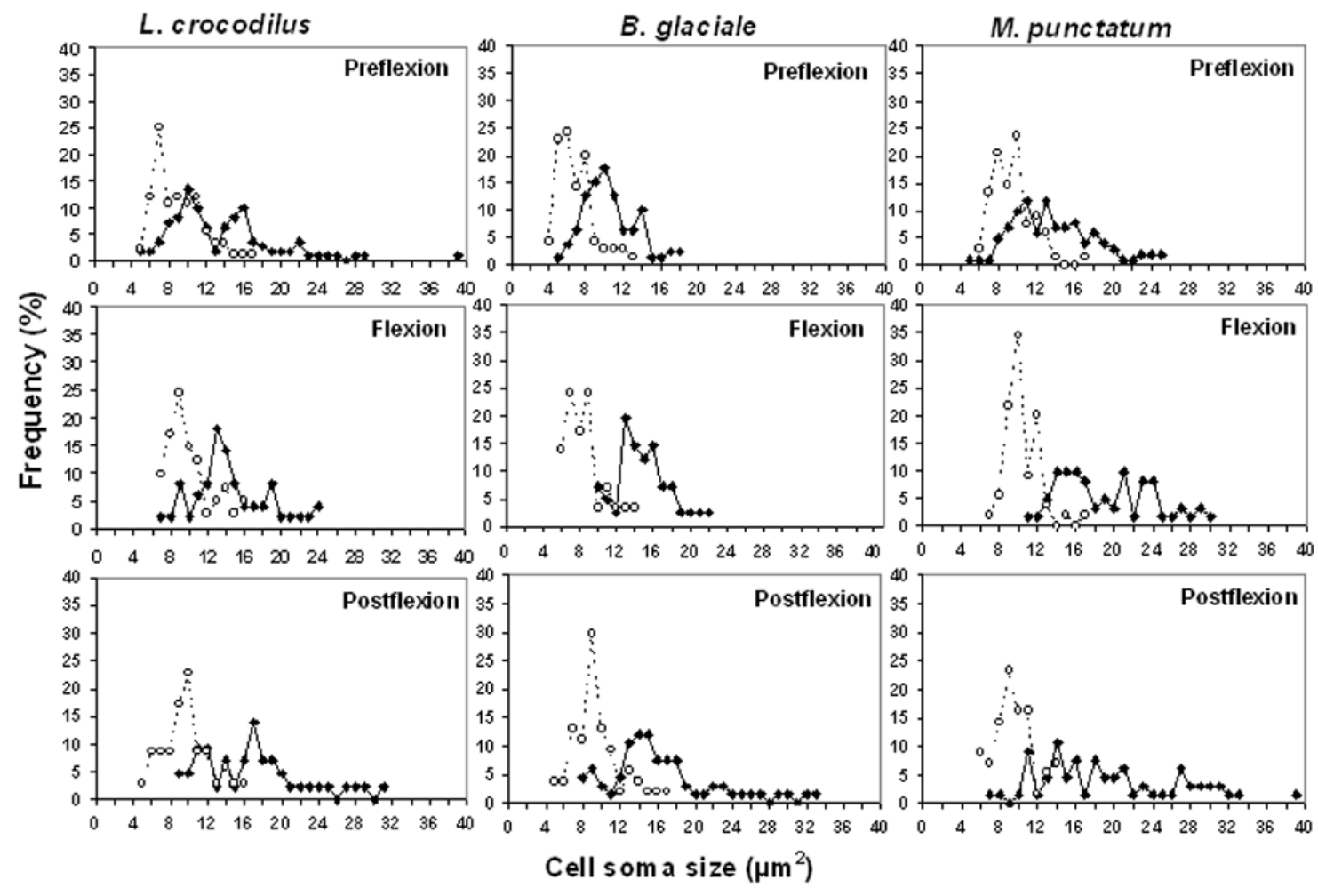

Fig. 7. Soma area versus frequency histograms of cell somata located within the GCL. The number of soma measures and the mean and stnadard deviation are listed in Table 3. Due to the relative low number of cells in the GCL, no matter was attended to discriminate between retinal areas. 
Table 3. Summary of the mean soma size $\left(\mu \mathrm{m}^{2}\right)$ and standard deviation (SD) of the cell population lying within the ganglion cell layer (GCL), of the putative ganglion cells (GC) and displaced amacrine cells (DAC). In brackets is indicated the DAC percentage relative to the total cells in the GCL

\begin{tabular}{|c|c|c|c|c|c|c|c|c|c|}
\hline & \multicolumn{3}{|c|}{ L. crocodilus } & \multicolumn{3}{|c|}{ B. glaciale } & \multicolumn{3}{|c|}{ M. punctatum } \\
\hline & $\begin{array}{l}\text { Cells in } \\
\text { the GCL }\end{array}$ & $\begin{array}{l}\text { Putative } \\
\text { GC }\end{array}$ & $\begin{array}{l}\text { Putative } \\
\text { DAC }\end{array}$ & $\begin{array}{l}\text { Cells in } \\
\text { the GCL }\end{array}$ & $\begin{array}{l}\text { Putative } \\
\text { GC }\end{array}$ & $\begin{array}{l}\text { Putative } \\
\text { DAC }\end{array}$ & $\begin{array}{l}\text { Cells in } \\
\text { the GCL }\end{array}$ & $\begin{array}{l}\text { Putative } \\
\text { GC }\end{array}$ & $\begin{array}{l}\text { Putative } \\
\text { DAC }\end{array}$ \\
\hline \multicolumn{10}{|l|}{ Pre-flexion } \\
\hline$n$ & 189 & 101 & $84 \quad(44 \%)$ & 199 & 108 & $124 \quad(62 \%)$ & 149 & 79 & $60 \quad(41 \%)$ \\
\hline Size $\left(\mu \mathrm{m}^{2}\right)$ & 12.1 & 14.4 & 9.5 & 11.7 & 13.7 & 9.3 & 9.3 & 11.0 & 7.4 \\
\hline SD & 4.3 & 4.4 & 2.1 & 4.9 & 5.5 & 2.5 & 3.1 & 2.8 & 2.0 \\
\hline \multicolumn{10}{|l|}{ Flexion } \\
\hline$n$ & 114 & 60 & $78 \quad(68 \%)$ & 88 & 48 & $38 \quad(43 \%)$ & 69 & 40 & $28 \quad(42 \%)$ \\
\hline Size $\left(\mu \mathrm{m}^{2}\right)$ & 15.5 & 19.8 & 10.8 & 12.8 & 14.7 & 10.5 & 12.5 & 15.1 & 8.9 \\
\hline SD & 5.8 & 4.9 & 1.7 & 3.9 & 3.8 & 2.4 & 3.9 & 2.7 & 2.0 \\
\hline \multicolumn{10}{|l|}{ Post-flexion } \\
\hline$n$ & 118 & 62 & $92 \quad(78 \%)$ & 74 & 40 & $30 \quad(41 \%)$ & 115 & 63 & $48 \quad(42 \%)$ \\
\hline Size $\left(\mu \mathrm{m}^{2}\right)$ & 15.3 & 20.1 & 10.0 & 13.7 & 16.7 & 10.1 & 13.3 & 16.3 & 9.7 \\
\hline SD & 7.8 & 7.9 & 2.1 & 5.2 & 4.9 & 2.4 & 5.4 & 5.4 & 2.3 \\
\hline
\end{tabular}

ences in rod OS lengths with retinal region, suggesting enhanced scotopic sensitivity in the dorsal and ventral planes compared to the central retinal regions.

Considering that the two species show an overlap in depth distribution, a difference of $50 \mathrm{~m}$ in the lower depth range means a difference of one order of magnitude in light intensity at midday $\left(1.3 \mu \mathrm{E} \mathrm{s}^{-1} \mathrm{~m}^{-2}\right.$ at $100 \mathrm{~m}$ depth vs. $0.10 \mu \mathrm{E} \mathrm{s}^{-1} \mathrm{~m}^{-2}$ at $\left.150 \mathrm{~m}\right)$ (Sabatés et al., 2003). In addition, the latter authors reported that larvae of both species showed distinct diel foraging patterns in relation to light intensity. In the case of $M$. punctatum larvae, feeding activity occurs mainly at dawn and dusk when light intensity can reach the threshold sensitivity $\left(1.8510^{-3} \mu \mathrm{E} \mathrm{s}^{-1} \mathrm{~m}^{-2}\right)$ for larval fish feeding proposed by Blaxter (1986).

Given the early development of rods, it is not surprising then that rod densities found in the pre-flexion stage of myctophid larvae were similar to those observed in larvae of other pelagic fish close to metamorphosis. For example, linear rod densities between 35 and 45 cells $100 \mu \mathrm{m}^{-1}$, corresponding to an angular density of $0.13-0.16$ cells per $10 \mathrm{~min}$ of arc, were consistent with those calculated in postflexion or premetamorphic larvae of Solea solea (Sandy \& Blaxter, 1980), Perca fluviatilis (Guma'a, 1982), Forsterygion varium (Pankhurst et al., 1993), Pagrus auratus (Pankhurst \& Eagar, 1996) and of three species of sciaenids (Poling \& Fuiman, 1998). Since rod photoreceptors are mainly associated with vision in low light intensities, the results may explain that light intensity thresholds for rod stimulation could be at least as important as other physical and biological variables in determining the taxonomic differences in depth distribution of these study species. In fact, the highest rod density calculated in the present study was in the larvae of $M$. puctatum, the species with the deepest distribution. Vertical zonation of fish larvae in relation to light intensity was also explained by Blaxter (1988), Leis (1991), and Job and Bellwood (2000).

At the pre-flexion stage, photopic visual acuity of lanternfish larvae was poor and varied greatly among species. For example, the best visual acuity calculated in the dorsal area of the retina of B. glaciale larvae, the species with the highest cone density among the studied species, was $1.4^{\circ} \mathrm{MSA}$ while visual acuity in $L$. crocodilus and M. punctatum were $6^{\circ}$ and $7.5^{\circ} \mathrm{MSA}$, respectively. Notwithstanding the limitations already stated in relation to esti- mates of visual acuity in the present study, these values were fairly consistent with visual prey detection by other planktivorous larvae. In fact, anatomical values of $4-6^{\circ}$ MSA were calculated in the larvae of Alosa pseudoharengus, Perca fluviatilis, and Clupea harengus (Blaxter \& Jones, 1967; Guma'a, 1982; Miller et al., 1993), while values of ca. 1-2 ${ }^{\circ}$ MSA were instead obtained in larvae of Premnas biaculeatus, Stethojulis strigiventer, Pleuronectes platessa, Scophthalmus maximus, Micropogonias undulates, Sciaenops ocellatus, Cynoscion nebulosus (Job \& Bellwood, 1996; Margulies, 1997; Neave, 1984; Poling \& Fuiman, 1998; Shand, 1997). Acuity of less than $1^{\circ}$ MSA (52') was calculated for larvae of Pagrus auratus (Pankhurst, 1994). Thus, theoretical acuities determined for first feeding fish larvae can range from $50 \mathrm{~min}$ of arc to $6-7^{\circ}$ MSA.

However, visual acuity reported for $M$. punctatum in the other retinal areas was inconsistent compared with the values indicated above for shallow water larvae.

In larvae of the three lanternfish species studied eye shape and position, along with body morphology, may be related with feeding strategies. Lanternfish larvae at these developmental stages are planktivorous and are assumed to be visual feeders, as their feeding activity is restricted to daylight hours (Sabatés et al., 2003). However, a contribution by non-visual senses to prey detection, especially in $M$. punctatum that show a quite low visual acuity, cannot be discounted as fish larvae frequently employ more than one sensory modality in prey detection (Pankhurst, 2007).

It has been reported that myctophid fish larvae exhibit a variety of feeding habits related to their morphological diversity (Sabatés \& Saiz, 2000; Sassa \& Kawaguchi, 2005). Body morphology of $L$. crocodilus larvae, with a deep body, laterally compressed head and large-toothed jaws (Moser et al., 1984) supports active pursuit of prey. In addition, the present study determined that the eyes of $L$. crocodilus were near spherical, located in an antero-lateral position and strongly angled inward toward the snout. The relatively large eye size that confers better acuity (because a given image is projected onto more photoreceptors) and presence of cone photoreceptors, mainly distributed in the centro-dorsal region of the retina, are consistent with a forward attacking visually mediated pursuit predator with binocular vision (Blaxter, 1965; Hobson \& Chess, 1986; Cobcroft \& Pankhurst, 2003, 2006). These characteristics are also 

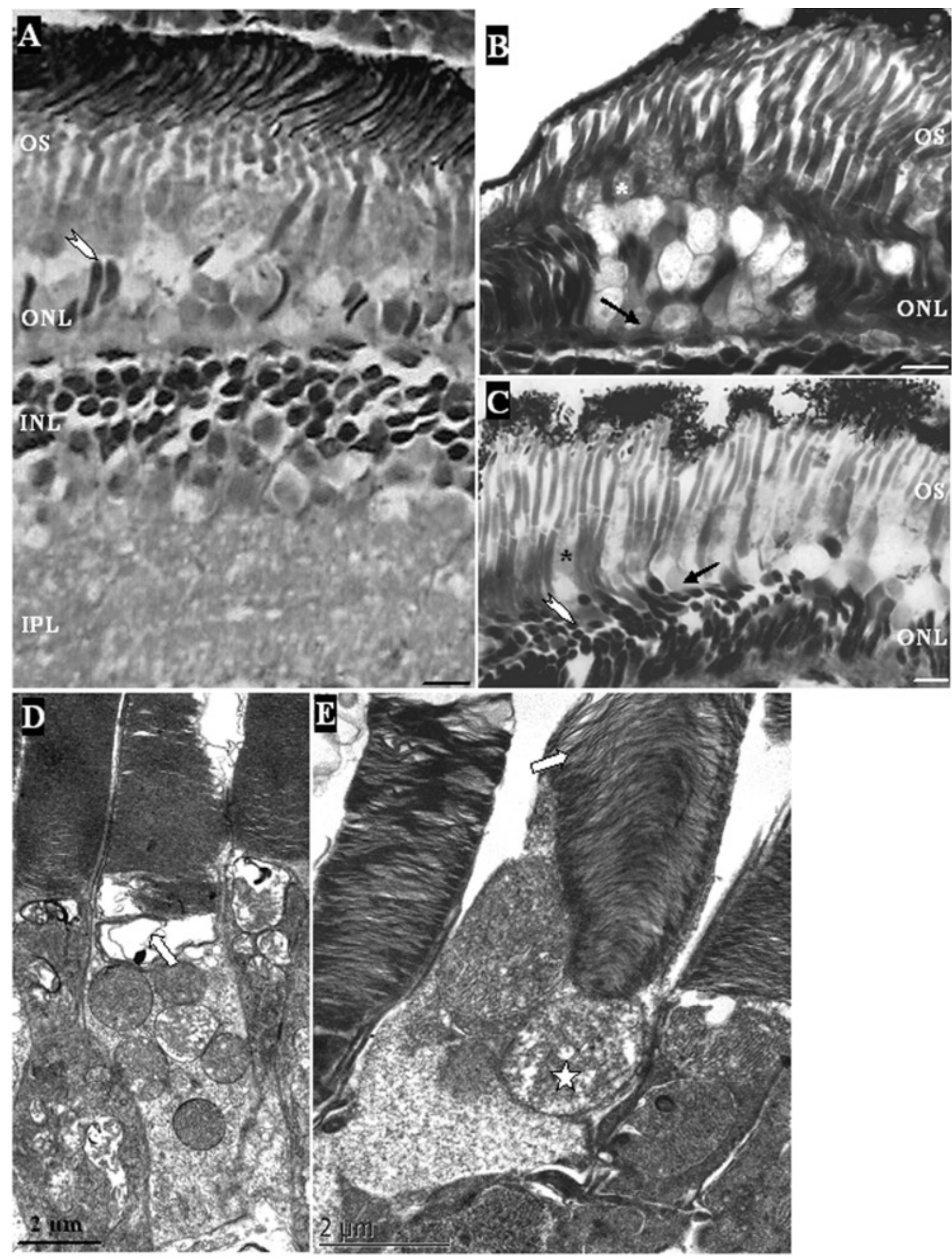

Fig. 8. (A-C) Light micrographs of the retinal outer nuclear layer in lanternfish larvae. The layer appear to be undergoing loss of presumptive cone nuclei (arrows) and inner segments (asterisk). In A most of the outer nuclear layer is constituted by degenerating nuclei and only few normal nuclei (white arrow) can be observed. In B a patch distribution of degenerating nuclei is observed (black arrow), while in $\mathrm{C}$ the degenerating cells are more regularly intercalated with the normal cells. (D-E) Transmission electron micrographs of the inner segments of the photoreceptors where cone OS lost their regular compact lamella structure, developing large inter-membrane spaces and separation of lamella discs (white arrows). Mitochondria also suffer degenerating process (white star). A and D, Lampanyctus crocodilus (6.75 mm SL); B and E, Myctophum punctatum (8 mm SL); C, Benthosema glaciale (7.6 mm SL). OS, outer segment; ONL, outer nuclear layer; INL, inner nuclear layer; IPL, inner plexiform layer. Scale bar (A-C): $6 \mu \mathrm{m}$. 


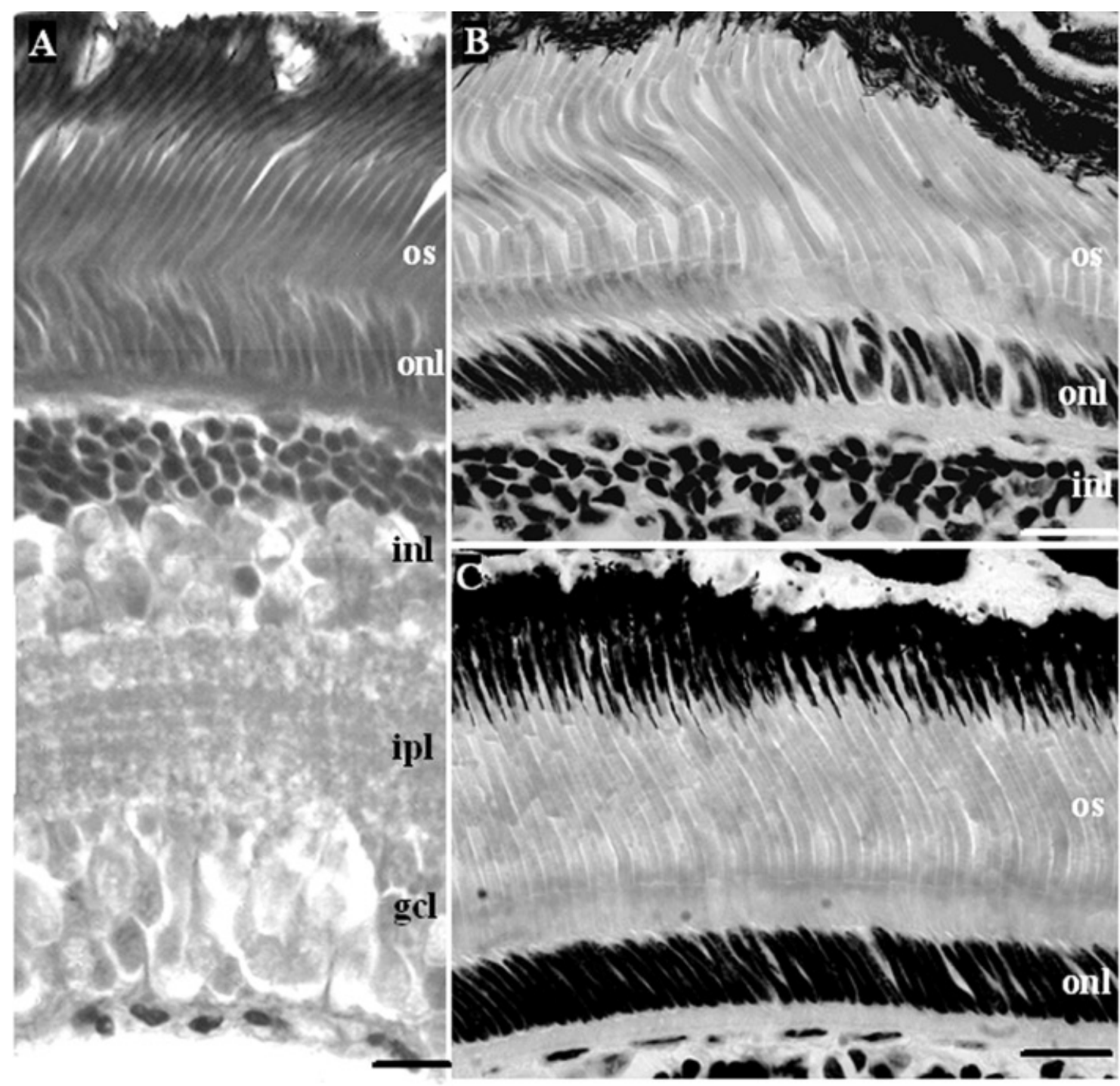

Fig. 9. (A) Light micrographs of the monolayered rod retinae of L. crocodilus (A), B. glaciale (B) and M. punctatum (C) in postflexion stage. Os, outer segment; onl, outer nuclear layer; inl, inner nuclear layer; ipl, inner plexiform layer; gcl, ganglion cell layer. Scale bar: $10 \mu \mathrm{m}$.

consistent with reports that larvae of this species feed during daytime in near-surface water (Sabatés \& Saiz, 2000).

The larvae of $B$. glaciale occupy a relatively wide range of depths (between 20 and $100 \mathrm{~m}$ ) compared to L. crocodilus larvae. Their body is fusiform, the mouth upturned and wide-spaced laterally-located elliptical eyes, suggest a lateral visual field extending in both dorsal and ventral planes. The combination of a dispersed array of cones, mainly in the centre of the retina, and the predominance of long rods in the periphery of the retina may confer on this species the ability to feed by visual means across its depth distribution throughout the daytime, as has been reported (Sabatés et al., 2003). The presence of cones suggests that acute visual perception is still important in preflexion larvae of this species when photopic conditions prevail, whereas rods may subserve prey detection, particularly in the dorsal and ventral visual fields, under scotopic conditions.

Pre-flexion larvae of $M$. punctatum, the species with the deepest distribution $(50-150 \mathrm{~m})$, have elongated bodies, wide mouths and broad dorso-ventrally flattened heads supporting small and strongly elliptical eyes borne at the end of stalks. These characteristics are shared with larvae of other species inhabiting relatively deep water including Bathylagidae and Idiacanthidae families (Weihs \& Moser, 1981; Moser et al., 1984). Lack of skeletal reinforcement in the eye stalks of $M$. punctatum larvae support our contention that these eyes can be freely rotated, potentially providing unimpeded vision in the lateral anterior and even dorsal planes and supports a conclusion by Weihs and Moser (1981) that stalked eyes of fish larvae allow a greater volume of water to be searched. An alternative and possibly not exclusive hypothesis, proposes that widely spaced eyes in larvae such as these reduce visibility to predators, the eyes being the most visible body feature (Johnsen, 2000). Similarly to B. glaciale, the elliptical nature of the eyes of $M$. punctatum would extend its visual field in the elongate axis. This body form, particularly the dorso-ventrally flattened head and mobile stalked eyes, seems to be consistent with an ambush predation strategy. If larvae hold the body horizontal with eyes projected upwards, this would presumably provide the possibility for larvae to detect prey passing overhead, silhouetted 
against the predominantly down-welling space light, as has been reported for other mesopelagic ambush predators (Locket, 1977). In comparison to the other myctophid species examined, cone density and acuity were lowest in preflexion larvae of $M$. punctatum. This and the associated domination of rods in the retina support visual function predominantly under scotopic conditions which is consistent with their depth profile and field studies that report their maximum feeding activity periods to be restricted to twilight (dawn and dusk) (Sabatés et al., 2003). Presumably if non-visual senses predominated in prey detection by this species then feeding periodicity would be expected to be less truncated.

\section{Flexion and Post-flexion stages}

In all three species of lanternfish examined, notochord flexion was accompanied by rapid development of the fin rays, changes in larval body shape and locomotive ability, like other fish larvae (Kendall et al., 1984). Unlike larvae of shallow water species that at this stage incorporate rod photoreceptors into the retina, the retinae of the lanternfish larvae were characterized by a dramatic decrease of cone density that almost disappeared in the late larval stage. Cones were also reported to disappear in the retina of leptocephalus stage Anguilla japonica ( $\geq 21.3 \mathrm{~mm}$ ) (Omura et al., 1997), while pure rod retinae were reported in early life history stages of some mesopelagic fish, including the leptocephalus stage of Anguilla anguilla ( $\geq 50 \mathrm{~mm}$ ) (Pankhurst, 1984), late stage larvae of a macrurid species ( $\geq 17 \mathrm{~mm} \mathrm{SL}$ ) (Blaxter \& Staines, 1970) and early juvenile viperfish Chauliodus sloani $(\geq 29 \mathrm{~mm}$ SL; Locket, 1980). Probably decrease and disappearance of cones observed in lanternfish larvae in advanced developmental stages occurs along with a general preparation for a change to a deep mesopelagic habitat. In fact, as the cones density declines, a progressive increase in the rod OS length was observed, especially in the dorsal retina, presumably with concomitant increase in rod photosensitivity. A positive correlation between the depth of occurrence and the length of the photoreceptor outer segments was also found in several species of adult mesopelagic fish (e.g., Locket, 1980; Pankhurst, 1987; Wagner et al., 1998). The increased summation ratio of rods: putative GCs observed in the retina of L. crocodilus, as well as the almost doubling of the DACs with respect to previous developmental stages also suggest a further adaptation process of the retina to the impending mesopelagic adult life. While the DACs role in the GCL is still unclear, it has been observed that the $80 \%$ of the total neural population in the GCL in the retina of adult lanternfish Lampanyctus macdonaldi was constituted by DACs (Wagner et al., 1998). It has been suggested by Mack et al. (2004) that, because of the proximity of DACs to GCs, the DACs can exert strong influence on the output activity of the GCs, on one side inhibiting the response from GCs (Nirenberg \& Meister, 1997), and on the other improving the detection of objects moving into the visual field of the eye. As the adults of $L$. crocodilus as well as $L$. macdonaldi can dwell in waters as deep as 1000-1200 m, an increase in movement detection can be useful in the predator-prey relationship.

During larval development, eye shape and position continue changing. The eyes of $B$. glaciale and $M$. punctatum became progressively rounded and the choroid gland reduced. In $M$. punctatum, both processes were also associated with an attenuation of the eye stalks and the final location of the eyes in the antero lateral orbits situated within the neurocranium. Rounding of the eyes and eyestalk absorption are processes likely to be associated with a significant metabolic oxygen demand that may indicate a role of the choroid glands. The new position of the eyes suggest that larvae of this species will now have binocular vision in the antero-lateral projecting visual field, and an active pursuit predator behaviour characteristic of other streamlined larvae (Pankhurst, 1994).

In conclusion, this study suggests that the early rod generation in lanternfish larvae may be related to the constraints associated with visual planktivory away from well-lit surface waters. On the other hand, although cones differentiated during the retina embryogenesis of these lanternfish larvae, their sequential loss and increase in rod OS lengths are interpreted as adaptive responses to an impending deep meso- and bathypelagic adult life. Changes in the location and orientation of eyes with respect to the head from pre-flexion to post-flexion stages and the progressive rounding of the eye shape were observed in Myctophinae species. These variations can be explained in terms of changes in visual ecology strategies in preparation to the deep habitat where light is less unidirectional. Therefore light could be an important physical factor that structures the vertical distribution of these species.

\section{Acknowledgments}

The work undertaken by AB at the James Cook University was supported by a Spanish Ministry of Science postdoctoral fellowship. PMP was supported by a James Cook University Aquaculture and Emerging Species Research Advancement Program grant. This work was supported by the European Union in the framework of the MAST Program (MAS-CT960051) and by a Spanish grant (REN 2002-01339/MAR). The samples for the transmission electron microscope were processed in the Unidad Técnica de Microscopía Electrónica of the Barcelona University. We thank two anonymous reviewers for their accurate and constructive criticisms on an earlier version of the manuscript.

\section{References}

Ali, M.A. \& KLYNE, M.A. (1985). Phylogeny and functional morphology of the vertebrate retina. In: Vertebrate Morphology, ed. Duncker/ Fleiscer. pp. 633-648. Stuttgart: Gustav Fisher Verlag.

BARNETT, C.H. (1951). The structure and function of the choroidal gland of teleostean fish. Journal of Anatomy 85, 113-119.

BlaXter, J.H.S. \& JONES, M.P. (1967). The development of the retina and retinomotor responses in the herring. Journal of the Marine Biological Association of the United Kingdom 47, 677-679.

BlaXter, J.H.S. \& Staines, M. (1970). Pure-cone retinae and retinomotor responses inlarval teleosts. Journal of the Marine Biological Association of the United Kingdom 50, 449-460.

BLAXTER, J.H.S. (1965). The feeding of herring larvae and their ecology in relation to feeding. California Cooperative Oceanic Fisheries Investigations. http://www.calcofi.org/newhome/publications/CalCOFI_ Reports/v10/pdfs/Vol_10_Blaxter.pdf

BLAXTER, J.H.S. (1986). Development of sense organs and behavior of teleost larvae with special reference to feeding and predator avoidance. Transactions of the American Fisheries Society 115, 98-114.

BlaXTeR, J.H.S. (1988). Sensory performance, behaviour, and ecology of fish. In Sensory Biology of Aquatic Animals, eds. Atema, J., Fay, R.R., Popper, A.N. \& Tavolga, W.N., pp. 203-232. New York: Springer-Verlag.

Cobcroft, J.M. \& Pankhurst, P.M. (2003). Sensory organ development in cultured striped trumpeter larvae Latris lineata: Implications for feeding behaviour. Marine and Freshwater Research 54, 669-684.

Cobcroft, J.M. \& Pankhurst, P.M. (2006). Visual field of cultured strimped trumpeter Latris lineata (Teleostei) larvae feeding on rotifer prey. Marine and Freshwater Behaviour and Physiology 39, 193-208.

Collin, S.P. (1988). The retinal structure of the shovel-nosed ray, Rhinobatos batillum (Rhinobatidae). Morphology and quantitative analysis of ganglion, amacrine and bipolar cell populations. Experimental Biology 47, 195-207.

Collin, S.P. \& Pettigrew, J.D. (1988). Retinal ganglion cell topography in teleosts: A comparison between Nissl stained material and retrograde labelling from the optic nerve. Journal of Comparative Neurology 276, $412-422$. 
Eastman, J.T. (1993). Antarctic Fish Biology: Evolution in a unique environment. San Diego: Academic Press.

GumA'A, S.A. (1982). Retinal development and retinomotor responses in perch, Perca fluviatilis L. Journal of Fish Biology 20, 611-618.

HirT, B. \& WAGNER, H-J. (2005). The organization of the inner retina in a pure-rod deep-sea fish. Brain, Behavior and Evolution 65, 157-167.

Hobson, E.S. \& Chess, J.R. (1986). Relationships among fishes and their prey in a nearshore sand community off southern California. Environmental Biology of Fish 17, 201-226.

Hopkins, T.L. \& GARTNER, J.J.V. (1992). Resource-partitioning and predation impact of a low-latitude myctophid community. Marine Biology 114, 185-197.

Job, S.D. \& Bellwood, D.R. (1996). Visual acuity and feeding in larval P. biaculeatus. Journal of Fish Biology 48, 952-963.

Job, S.D. \& Bellwood, D.R. (2000). Light sensitivity in larval fish: Implications for vertical zonation in the pelagic zone. Limnology and Oceanography 45, 362-371.

Johnsen, S. (2000). Transparent animals. Scientific American February, $80-89$.

Kawamura, G., Tsuda, R., Kumai, H. \& Ohashi, S. (1984). The visual cell morphology of Pagrus major and its adaptive changes with shift from pelagic to benthic habitats. Bulletin of the Japanese society of Scientific Fisheries 50, 1975-1980.

Kendall, Jr., A.W., Ahlstrom, E.H. \& Moser, H.G. (1984). Early life history stages of fishes and their characters. In Ontogeny and systematic of fishes, eds. Moser, H.G., Richards, W.J., Cohen, D.M., Fahay, M.P., Kendall, A.W. \& Richardson, S.L., pp. 11-22. Lawrence, KS: Allen Press Inc.

Kotrschal, K., Adam, H., Brandstätter, R., Junger, H., Zaunreiter, M. \& Goldschmid, A. (1990). Larval size constraints determine directional ontogenetic shift in the visual system of teleosts. Zeitschrift fuer Zoologische Systematik und Evolutionsforschung 28, 166-182.

LARA, M.R. (2001). Morphology of the eye and visual acuities in the settlement-intervals of some coral reef fishes (Labridae, Scaridae). Environmental Biology of Fishes 62, 365-378.

LEIS, J.M. (1991). The pelagic stage of reef fishes: The larval biology of coral reef fishes. In The Ecology of Fish on Coral Reefs, ed. Sale, P.F., pp. 183-230. San Diego: Academic Press.

Locket, N.A. (1977). Adaptations to deep-sea environment. In The Visual System in Vertebrates. Handbook of Sensory Physiology, Vol. 8, 5th edition, ed. Crescitelli, F., pp 67-192. NewYork: Springer.

LOCKET, N.A. (1980). Variation of architecture with size in the multiplebank retina of a deep-sea teleost, Chaoliodus sloanei. Proceeding of the Royal Society of London B 208, 223-242.

Mack, A.F., Süssmann, C., Hirt, B. \& Wagner, H.J. (2004). Displaced amacrine cells disappear from the ganglion cell layer in the central retina of adult fish during growth. Investigative Ophthalmology and Visual Science 45, 3749-3755.

Margulies, D. (1997). Development of the visual system and inferred performance capabilities of larval and early juvenile scombrids. Marine and Freshwater Behaviour and Physiology 30, 75-98.

MatsuoKa, M. (1999). Histological characteristics and development of the retina in the Japanese sardine Sardinopsis melanostictus. Fisheries Science 65, 224-229.

Miller, T.J., Crowder, L.B. \& Rice, J.A. (1993). Ontogenetic changes in behavioural and histological measures of visual acuity in three species of fish. Environmental Biology of Fishes 37, 1-8.

Moku, M., Mori, K. \& Watanabe, Y. (2004). Shrinkage in the body length of myctophid fish (Diaphus slender-type spp.) larvae with various preservatives Copeia 3, 647-651.

Moku, M., Iishimaru, K. \& Kawaguchi, K. (2001). Growth of larval and juvenile Diaphus theta (Pisces: Myctophidae) in the transitional waters of the western North Pacific. Ichthyological Research 48, 385-390.

Moser, H. G. \& Ahlstrom, E.H. (1970). Development of lanternfishes (family Myctophidae) in the California Current. Part I. Species with narrow-eyed larvae. Bulletin of the Los Angeles County Museum of Natural History Science 7.

Moser, H. G. (1981). Morphological and functional aspects of marine fish larvae. In Marine Fish Larvae: Morphology, Ecology and Relation to Fisheries, ed. Lasker, R., pp. 89-31. Seattle, WA: University of Washington Press.

Moser, H.G. \& Ahlstrom, E.H. (1974). Role of larval stages in systematic investigations of marine teleosts: The Myctophidae, a case study. Fishery Bulletin 72, 391-413.

Moser, H.G., Richards, W.J., Cohen, D.M., Fahay, M.P., Kendall,
A.W. \& RichaRdSON, S.L. (1984). Ontogeny and Systematics of Fishes. Lawarence, KS: Allen Press Inc.

NeAve, D.A. (1984). The development of the retinomotor reactions in larval plaice (Pleuronectes platessa, L.) and turbot (Scophthalmus maximum, L.). Journal Experimental Marine Biology and Ecology 76, $167-175$.

NiCOL, J.A.C. (1989). The Eyes of Fishes. Oxford: Clarendon Press.

NirenberG, S. \& Meister, M. (1997). The light response of retinal ganglion cells is truncated by a displaced amacrine circuit. Neuron 18, $637-650$.

O'Day, W.T. \& Fernandez, H.R. (1976). Vision in the lanternfish Stenobrachius leucopsaurus (Myctophidae). Marine Biology 37, 187-195.

Olivar, M.P \& SABAtÉs, A. (1997). Vertical distribution of fish larvae in the north-west Mediterranean Sea in spring. Marine Biology 129, 289-300.

Olivar, M.P., Rubíes, P. \& Salat, J. (1992). Horizontal and vertical distribution patterns of ichthyoplankton under intense upwelling regimes off Namibia. South African Journal of Marine Science 12 71-82.

Olivar, M.P., Sabatés A., Abelló P. \& García M. (1998). Transitory hydrographic structures and distribution of fish larvae and neustonic crustaceans in the north-western Mediterranean. Oceanologica Acta 21, 95-104.

Omura, Y., Uematsu, K., Tachiki, H., Furukawa, K. \& Satoh, H. (1997). Cone cells appear also in the retina of eel larvae. Fisheries Science 63, 1052-1053.

Pankhurst, N.W. (1984). Retinal development in larval and juvenile European eel, Anguilla anguilla (L.). Canadian Journal of Zoology 62 , $335-343$.

PANKHURST, N.W. (1987). Intra- and interspecific changes in retinal morphology among mesopelagic and demersal teleosts from the slope water of New Zeland. Environmental Biology of Fishes 19, 269-280.

Pankhurst, P.M. \& EAgar, R. (1996). Changes in visual morphology through life history stages of the New Zealand snapper, Pagrus auratus. New Zealand Journal of Marine and Freshwater Research 30, 79-90.

PAnkhurst, P.M. \& Hilder, P.E. (1998). Effect of light intensity on feeding of striped trumpeter Latris lineate larvae. Marine and Freshwater Research 49, 363-368.

PAnkhurst, P.M. (1994). Age-related changes in the visual acuity of larvae of New Zealand snapper, Pagrus auratus. Journal of the Marine Biological Association of the United Kingdom 74, 337-349.

Pankhurst, P.M. (2007). Mechanoreception. In Fish Larvae Physiology, ed. Finn, R.N. Science Publisher Inc.

Pankhurst, P.M., Pankhurst, N.W. \& Montgomery, J.C. (1993). Comparison of behavioural and morphological measures of visual acuity during ontogeny in the teleosts fish, Forsterygion varium, Tripterygiidae (Foster, 1801). Brain, Behaviour and Evolution 42, 178-188.

PAXton, J.R. (1972). Osteology and relationships of the lanternfishes (Family Myctophidae). Bulletin of the Los Angeles City of the Musum of the Natural History Science 13, 81.

Poling, K.R. \& Fuiman, L.A. (1998). Sensory development and its relation to habitat change in three species of scianidae. Brain Behavior and Evolution 52, 270-284.

Powers, M.K. \& RAYMOND, P.A. (1990). Development of the visual system. In The Visual System of Fishes, eds. Douglas, R.H. \& Djamgoz M.B.A., pp. 419-442. London, UK: Chapman and Hall.

Rodríguez, A. \& Gisbert, E. (2002). Eye development and the role of vision during Siberian sturgeon early ontogeny. Journal of Applied Ichthyology 18, 280-285.

SABATÉs, A. (2004). Diel variability of fish larvae distribution during the winter mixing period in the NW Mediterranean. ICES Journal of Marine Science 61, 1243-1252.

SABATÉs, A. \& SAIZ, E. (2000). Intra- and interspecific variability in prey size and niche breadth of myctophiform fish larvae. Marine Ecology Progress Series 201, 261-271.

Sabatés, A., Bozzano, A. \& Vallvey I. (2003). Feeding pattern and the visual light environment in myctophid fish larvae. Journal of Fish Biology 63, 1476-1490.

Sameoto, D.D. (1988). Feeding of lanternfish Benthosema glaciale off the Nova Scotia shelf. Marine Ecology Progress Series 44, 113-129.

SANDY, J.M. \& BlaXTER, J.H.S. (1980). A study of retinal development in larval herring and sole. Journal of the Marine Biology Association of the United Kingdom 60, 59-71.

Sassa, C. \& Kawaguchi, K. (2005). Larval feeding habits of Diaphus theta, Protomyctophum thompsoni and Tarletonbeania taylori (Pisces: 
Myctophidae) in the transition region of the western North Pacific. Marine Ecology Progress Series 298, 261-276.

SHAND, J. (1997). Ontogenetic changes in retinal structure and visual acuity: a comparative study of coral-reef teleosts with differing postsettlement lifestyles. Environmental Biology of Fishes 49, 307-322.

ShAND, J., ArCher, M.A. \& Collin, S.P. (1999a). Ontogenetic changes in the retinal photoreceptor mosaic in a fish, the black bream, Acanthopagrus butcheri. The Journal of Comparative Neurology 412, 203-217.

Shand, J., Døving, K.B. \& Collin, S.P. (1999b). Optics of the develop- ing fish eye: Comparisons of Matthiessen's ratio and the focal length of the lens in the black bream Acanthopagrus butcheri. Vision Research 39, 1071-1078.

Wagner, H.J., Frohlich, E., Negishi, K. \& Collin, S.P. (1998). The eyes of deep-sea fish. II. Functional morphology of the retina. Progress in Retinal and Eye Research 17, 637-685.

WeIrs, D. \& Moser, H.G. (1981). Stalked eyes as an adaptation towards more efficient foraging in marine fish larvae. Bulletin of Marine Science 3, 31-36. 